\title{
Miranda
}

Revue pluridisciplinaire du monde anglophone /

Multidisciplinary peer-reviewed journal on the English-

speaking world

19 | 2019

Rethinking Laughter in Contemporary Anglophone Theatre

\section{Laughing Out Young: Laughter in Evan Placey's Girls Like That and Other Plays for Teenagers (2016)}

\section{Claire Hélie}

\section{OpenEdition}

\section{Journals}

Electronic version

URL: http://journals.openedition.org/miranda/20064

DOI: 10.4000/miranda.20064

ISSN: 2108-6559

\section{Publisher}

Université Toulouse - Jean Jaurès

\section{Printed version}

Date of publication: 7 October 2019

\section{Electronic reference}

Claire Hélie, "Laughing Out Young: Laughter in Evan Placey's Girls Like That and Other Plays for Teenagers (2016)", Miranda [Online], 19 | 2019, Online since 09 October 2019, connection on 16 February 2021. URL: http://journals.openedition.org/miranda/20064 ; DOI: https://doi.org/10.4000/ miranda.20064

This text was automatically generated on 16 February 2021

\section{(c)}

Miranda is licensed under a Creative Commons Attribution-NonCommercial-NoDerivatives 4.0 International License. 


\title{
Laughing Out Young: Laughter in Evan Placey's Girls Like That and Other Plays for Teenagers (2016)
}

\author{
Claire Hélie
}

1 Evan Placey ${ }^{1}$ is a Canadian-British playwright who writes for young audiences; but unlike playwrights such as Edward Bond, Dennis Kelly or Tim Crouch, he writes for young audiences only. Some of his plays target young children, like WiLd! (2016), the monologue of an 8-year-old boy with ADHD (Attention Deficit Hyperactivity Disorder), other young adults, like Consensual (2015), which explores the grey area between rape and consent. His favourite audience remain teenagers and four of the plays he wrote for them were collected in Girls Like That and Other Plays for Teenagers in 2016.

His plays have been performed in many teen theatre festivals, like the 2014 National Theatre Connections, an annual youth theatre festival in London during which ten plays from established playwrights are performed by youth theatre groups (plays by Enda Walsh, Mark Ravenhill, Howard Brenton or Alice Birch have featured in this festival). Girls Like That was awarded the Best Play for Young Audiences at the 2015 Writers' Guild of Great Britain Awards. His plays have travelled all over the world and received critical acclaim. In France for instance, his plays were translated and performed during the 2015 Mousson d'hiver, the 2017 Regards Croisés, the 2018 Mousson d'été, to name but a few. His work is usually well received by the press and seen as an essential tool to help teenagers through the growing process and out of the pitfalls of adolescence. For instance, he is featured along Christine Quintana in "Teaching teens about \#MeToo Through Theatre". Instructors seem to see the didactic potential of Placey's work and almost all his plays come with a "teachers' resource pack" that will help teachers bring the plays to their students' attention in class before watching them on stage. Performances can be given by professional young actors, but are also big hits among amateur groups from high school to university (Webb Schools in 2014, Princeton in 2017, Islington in 2018...) When performed at Edmonton 
Highschool in 2017, student reviewers all praised one of the actresses for her comic potential which gave them "fits of laughter".

Unsurprisingly, in his plays, which give a panoramic view of what adolescence is, Evan Placey portrays teenagers laughing a lot through puberty and life crises. Descartes had his cogito, youth have their "I laugh therefore I am." As we shall see, paradoxically, these laughing-out-young moments, which are simultaneously dramatic gestures on stage and means of communication with the audience, are both naturalistic in that they induce a youth effect (as in Roland Barthes's "effet de réel") which aims at creating empathy, and anti-naturalistic in that character repeatedly question the source and target of laughter, thus introducing a Brechtian distancing effect.

\section{Laughter in Evan Placey's Plays for Teenagers: Some Definitions}

4 Adolescence is researched in many different fields - sociology, psychology and psychiatry to name but a few; it even has its own branch in medicine, named hebiatrics. It is consistently defined as the transition undergone when a child, going through puberty, develops into an adult. From a physiological perspective, laughing is a way to discharge the tension accumulated and it helps bring release. According to Victorian philosopher Herbert Spencer in On the Physiology of Laughter, "Laughter naturally results only when consciousness is unawares transferred from great things to small-only when there is what we call a descending incongruity" (Spencer 225). In other words, laughter makes the release of pent-up energy possible. Since adolescence is characterised by many hormonal changes, laughing works as some sort of emotional thermostat, a defence mechanism when the body is under a lot of stress because of puberty. Psychiatrist Jean-Pierre Kamieniak also insists on the idea that humour is a response to physiological and psychical changes. Indeed, the traditional image of adolescents in a state of advanced lethargy on their sofa competes with that of a group of young people laughing together, or more likely, laughing at one another, in an attempt to meet the Other. Teenagers laugh about the same things; it is a way for them to check whether they share common fantasies. It is also a way for them to bond with other teens, which is why sociologists like Olivier Galland and Dominique Pasquier insist on the cultural dimension of adolescence which they claim is defined by "peer culture" and "horizontal sociability" on the one hand, and generational conflict on the other (Galland 5, my translation). Indeed, the concept of what makes adolescents laugh is not so easy to grasp and adults, whether educators or parents, often feel like old bores when in a room filled with young people. As Bergson demonstrated, laughter has a normative function: it is a social correction to any form of social abnormality and being an adult is not normal in a teen's world, which makes it very challenging for artists to write for young audiences.

Theatre for young audiences remains an elusive term though. It is basically defined by its target audience, which seems to be exclusive of older audiences, even though childcarers and instructors are necessarily involved in the process, be it only by buying the ticket or giving a lift to the theatre. In the case of Girls Like That and other Plays for Teenagers, the audience are supposedly teens, between the age of 13 and 19, exactly the same age as the young people on the cover mugshots. The title play was commissioned by and performed at The Unicorn Theatre, a London theatre dedicated to children and 
young adults aged 2 to 21 , it is regularly put on in schools and it won the 2015 Scenic Youth Award in Béthune (among other prizes). The other plays have received similar commissions and reception too.

6 This audience target suggests three features that seem to be common to all plays for teenagers in terms of themes, characters and intentions. Indeed, the themes developed are related to adolescence and the action is more often than not located on school grounds. Banana Boys (2011) is almost a coming-out story - the homosexuality of the captain of the football team is revealed, which forces him and his friends to reassess their friendship. Holloway Jones (2011) raises the question of determinism through the story of a girl who was born in prison, was named after a prison and whose mother is still in prison: is Holloway doomed to end up in prison or can BMX provide her with a way out? Girls Like That (2013) follows Scarlett, or rather her classmates, after a naked picture of her is circulated at school and she becomes the victim of constant bullying. Pronoun (2014) is a comedy based on a group of friends who need to renegotiate the terms of their relationships when one of them goes through gender reassignment. Consequently, almost all the characters and actors are the same age as the audience: the different dramatis personae specify the main characters are teenagers. People over 20 are usually figures of authority like parents, guards or teachers, who have minor roles to play, and who, more often than not, do not manage to solve the teenagers' problems. For instance, in Banana Boys, the Banana Girls are a group of Black singers in their early twenties who act as an ironic, non-committal musical counterpoint to Cameron's coming out story. In Holloway Jones, the mother, a tragi-comic character, does not have a clue about what her daughter is going through, even though she starts supporting her before the curtain falls. Finally, the author's intentions also help classify a play as a play for young audiences. In the case of Placey's collection, it is plainly seen in the choice of the subtitle and in the preface where the playwright repeatedly mentions - though hardly ever directly addresses - his target audience: "I write plays for young people, [...] we need theatre for young audiences, [...] we need plays for young people"... He concludes with a send-off that insists on the virtues of self-derision and laughing: "And like the fairy godmother sending you off to the ball I must say, 'Remember to have fun.' I certainly had loads of fun writing [these plays]" (Placey xiv).

7 Placey knows he is treading on a thin line here because theatre for young audiences is always at risk of falling into one or the other of two pitfalls: escapism and didacticism. Though his plays provide entertainment, they confront situations adolescents can experience in real life. Besides, he constantly rejects the label "cautionary tale" for his plays. In a lecture he gave at Lille University in 2015, he said,

There isn't a moral or message in these plays, so don't try to find one. There aren't any answers either. I don't have them. But maybe these plays can act as provocations for young people to find the answers. It's they who must find them. It's their future. (Placey 2015)

8 In other words, Placey wants to tackle moral subjects without moralising, and he does so by opening a dialogue. In claiming, "it's up to you, it's up to the audience", he conforms to the definition given by Marie Bernanoce and Sandrine Le Pors of what theatre for young audiences should be, that is to say, "a commitment which extends beyond theatre for young people and which questions both the world and theatre, youth and adulthood attempting to look at the world as it has been since its childhood"2. 


\section{Laughter in the Text: Locating and categorizing the "youth effect"}

9 There is a rather wide range of comic types in Placey's plays for teenagers, and some scenes show the characters laughing, which is sometimes indicated in the stage directions. It should be noted that the very presence of the word laughter in playtexts has evolved in time. For instance, all the references to laughter were erased from early editions of Shakespeare because they pointed to the realities of the material body; on the contrary, in Beckett, the word is used repeatedly and modulated in terms of length, pitch and type, because it is part of an experimental presence of the body on stage (Pfister 178). Placey's use of the word "laughter" in the stage directions is not consistent from one play to the other. The word appears 11 times in Holloway Jones (and the word "smiles" three times) whereas it is used just once in Girls Like That, which, incidentally, does not contain many stage directions, as opposed to the other plays. What is interesting in these numbers is that this non-verbal mode of expression is always described through the same word, "laugh", whereas Placey uses a greater variety of words to convey tone (sarcastic, ironic...) and pitch ("she screams", "in a whisper"...) in verbal modes of expression. Besides, allusions to laughing are not frequent in implicit stage directions, when a character mentions or comments upon his/her own laughter or upon the laughter of the characters on stage. Nor is phonetically transcribed laughter (the three syllables "ha ha ha") to be found in the dialogues. Even when there are straightforward allusions to laughter, they do not come in early. For instance, in Banana Boys, the word appears in the stage directions for the first time after 13 pages of script and after a lot of joking and humour. In other words, evidence that the characters should laugh is sparse. And yet, they do, and so do the audience.

Laughter can be triggered by situations fraught with puns and wordplays that suggest a communion of minds. For instance, in Banana Boys, while in a sex-ed class, Ben, who is openly homosexual and being bullied for that, is working with Cameron, who is about to come out. They have been assigned the task of putting a condom on a banana:

CAMERON (pinches the top while Ben rolls it down) What happens if you don't pinch it? BEN Banana split.

They share a laugh. (48)

11 The joke here is not detrimental to anyone, it is rather benign and yet effective in releasing the sexual tension between the two boys who find a way to communicate through laughter. Yet, while laughter can be benevolent when triggered by a spirit of resilience and sharing, it is more often than not generated by giving a tragic-comic twist to anagnorisis, especially when the characters come to realise that life is full of ironies and there is no way of escaping them. One such example is provided by Holloway Jones who narrates an episode of her life when her foster family gave her a very old bike and she practised hard at night to make them proud. One night, she forgot to lock the garage where the bike was kept - everything that was stored in the garage was stolen and she was removed from the family. She then laughs and tells the audience why: "Cleared everything from the garage, but left the bike, rubbish old thing" (126). Laughing is necessary to live past such absurdities which have dramatic consequences. Indeed, Evan Placey strongly believes in laughter as a sign and means of 
resilience. He said about his work with prisoners on Holloway Jones: "What inspired me about the storytellers was the sense of hope, of second chances, and the humour to be found in the most saddening situation" (Placey 3). Laughter is redeeming when the character is faced with the comic dimension of human experience.

If facing the absurdities of life is not restricted to a specific age group, coming to terms with a sense of ridicule because your body has urges that are beyond control may well be a hallmark of adolescence. No matter how meaningless the experience of teenage life becomes, never does Placey explore the Theatre of the Absurd - on the contrary, his work renews a deep faith in the possibilities of communication to bring redemption. Adolescence is a stage and laughing can help young people go through it.

Psychologists have classified adolescent laughter into three categories: gelotophilia, or the joy at being laughed at, at experiencing embarrassment; gelotophobia, or the fear of being laughed at, of being victimized; and katageliasticism, or the joy in laughing at others, in observing something embarrassing in other people (Proyer et al., 399-420). These three categories are given a specific young dimension by being set on school grounds.

14 Gelotophilia is embodied by characters acting silly, especially while discussing body changes, sexuality and modesty. In Banana Boys, there are two corresponding scenes in the first one, the girl gang is discussing relationships with men in the light of feminism; in the second one, the boy gang is discussing relationships with women in the light of virility. The conversation is lively, but only do they burst out laughing when one of the characters goofily brags about having sex, which the other characters think is incongruous and discard both times by exclaiming, "Shut up. You haven't even done it" (Placey 19, 40). Self-derision and allusions to the life of the body thus offer a counterpoint to the intellectualization of relationships.

Gelotophobia is not actualized in the present but belongs to the realm of fantasies, of alternate realities. For instance, in Banana Boys, when Calum discovers his brother and his girlfriend have been seeing each other, he asks, "Were you gonna tell me? Or you two just gonna keep laughing behind my back?" (Placey 92) In Holloway Jones, the fear of being laughed at again for being "a charity case" who dreams too big for her condition, as happened to Holloway after she won a race fair and square, gives the young girl the stamina she needs to train even harder but also turns her into someone looking for revenge as she imagines her future self asking her past bullies, "Who's laughing now?" (Placey 114-116) Gelotophobia thus relates to the philosophical trend that sees laughter as evil, but it does not belong to the here and now.

Katageliasticism is omnipresent in Placey's plays because the issue of bullying is so central to his work. In Girls Like That, the students will laugh at Scarlett's naked body but those whose ethics are exposed are the laughers. Indeed, Scarlett has no harmatia to account for: the identity of the person who took and circulated the photo is never elucidated and the play makes it clear that she cannot be held responsible for other people's reaction to her misfortune and that she will grow past these mean girls. Yet Placey does not overuse the castigat mores ridendo mode, even if he has one revenge scene in Banana Boys. Prom is coming and Riley has refused to go to the dance with Tanisha after she had sex with him, which he bragged about. Alisha therefore plans a practical joke by tricking him into taking a picture of his genitalia. She then sends it around so that everyone sees it and laughs at him as a form of collective punishment. 
Riley thus has a taste of his own medicine and through the exposure of his private part, it is his lack of ethics that is actually exposed.

\section{Laughter on stage: Moulding Group Structures}

17 Whether the teenagers represented on stage mean good or evil, laughing is a way for them to question or reassess their position in the group, to find their place in "the pecking order", the school implicit hierarchy in the words of the mean girls. Placey is used to a modus operandi when under commission to write a play for young audiences: he writes a first draft of the play, then he runs a workshop around the theme and form of the play with teenagers, a phase during which he makes a few changes to come closer to the world of his characters, and finally, he writes the version that will be put up. Even though he listens very carefully to what teenagers say to him and to how they say it, it is not verbatim theatre, except on very rare occasions. For instance, he mentions one joke he inserted in Girls Like That after a conversation with a young girl: "Like my brother says: if a key can open a lot of locks, it's a really good key. Like a master key. But if a lock can be opened by lots of keys then it's a really shit lock. Do you see?" (Placey 201) The humour here is based on the analogy of key and lock with male and female genitalia. What the analogy hides is the double standard that allows (or forces?) boys to have a lot of sex while girls must stay virgin (or at least silent about their sexuality). Laughter is elicited by the gap introduced by the analogy between the unquestioned social order and the disorder that language brings in. Laughing out loud thus participates in the youth effect - the actors look like teenagers and their characters speak and act like teenagers. Studying the modalities of laughter on stage makes it easier to understand the dramatic tensions between the characters, but also fosters the process of identification between the characters, depending on their age and gender.

Yet, readers and audience are not expected to identify with the laugher - they are far more likely to be on the side of the one who is being laughed at. For instance, in the parlour scene in Holloway Jones, Holloway's mother is first introduced as an insane woman, unable to recollect her memories, let alone the exact date of her daughter's birthday, prone to using her as a mule and bent on abusing her verbally: "Got Alzheimer's or something?" (Placey 118) "You some Naomi Campbell now?" (Placey $119)$, a reference to the 90 s when supermodels were attracting high media coverage that may be lost on most teenagers. The whole scene is framed by an image of the mother laughing, the first time "hysterically", while the second occurrence gives way to manipulative tears since she wants her daughter to hand her a handkerchief filled with drug. Even though the mother claims "You have your mum's sense of humour", never does Holloway actually vilify others for fun. These hysterical and fake laughs enable the audience to see the distance between Holloway and her mother and therefore to pity and identify with the young girl.

Beside being related to age, laughing is also gendered: whereas the word "laugh" is systematically used for boys, the word "giggle", which refers to a silly type of laughter that is due to embarrassment, is sometimes used for girls. In Banana Boys, it is used twice for Tanisha when she is locked up in a closet with Riley at a party and is trapped into showing him her breasts in exchange for some money she has "borrowed" and 
lost. "Giggle" here is used to make it explicit that the girl is not trying to flirt with the boy but that she is ill-at-ease with the sexual tension generated by the situation.

Furthermore, laughing as a male group activity can be enhanced by other dramatic gestures borrowed from youth culture. This is obvious with high-fiving. In one of the many locker room scenes in Banana Boys, Zach and Max are making fun of Callum who has expressed his love to his girlfriend, who only replied with a cinematic and laconic "Ditto". The stage direction "they laugh" is used three times over two pages and after Max says, "No giving flowers till you've deflowered" (Placey 84), he high-fives Zach, a recurring gesture to stress comradeship in laughter. In Girls Like That, one of the girls confirms the gendered nature of laughing. After one of the boys teases Scarlett with taunting words that make everybody laugh, the girl notices:

The boys laugh, some of them high-five.

I've never really understood the high-fives. When I was twelve I tried it out, started high-fiving my best friend every time I saw her or I made a joke. But it just never really took off. (Placey 191)

Therefore laughter has an important social role to play, namely that of moulding group structures, since it functions as a meta-communicative signal in society. René Girard in La Violence et le Sacré explained that the expulsion of the scapegoat - and laughing at someone is a way of expelling them from the herd - ensures the cohesion of the group. In Banana Boys, laughter is more often than not presented as a group activity: "they all laugh" (Placey 19), "they share a laugh" (Placey 48). Everyone has a role to play in the production of laughter: the one who generates laughter, the one who is the victim of laughter, the one who laughs, the one who does not laugh... and not only can the roles switch but the situation can be interpreted in very different ways depending on who is involved. For instance, there are two similar locker room episodes in Banana Boys that involve a game of piggy in the middle, first with Calum, who is a respected member of the group, who enjoys the game and takes part in it by laughing; then with Ben who is an outcast because of his homosexuality and make-up and who does not take part in the general jubilation. Thus, laughs participate in showing, rather than telling, the nature of the social relations between the different characters.

When used in a symbolic way to pit childhood against adolescence, laughing or not may suggest evolution in time. For instance, there are numerous flashbacks in Girls Like That, the second of which shows the girls when they were eight. After an afternoon of merriment, all the girls lie down in a perfect circle, touching each other, until one starts giggling because of a tickle and the next one does the same and the next one too until all the girls laugh together (Placey 194-195). What this contagious laugh shows is that the unity between the girls comes from a recognition of a connectedness in their bodies, a connectedness that puberty and smartphones put an end to by turning Scarlett's body into a virtual image that is no longer her real body, not even her body at all. Throughout the play, there is a nostalgia for this moment of bonding and laughter. The emotional distance introduced with Scarlett's physical body once it goes digital makes a more cynical type of laughter emerge - one that is normative in the Bergsonian sense of the word. Paradoxically, laughing at Scarlett, excluding her from the group, allows the other girls to pretend that the group still exists, be it for a brief moment. When Scarlett leaves the school and the body of a drowned girl is found, the girls unite again, this time in tears. But when she reappears, as if she were a ghost with a vengeance, her physical presence, the link that has been missing since they were eight, forces the group to dissolve. In one of the final scenes, at the end of the year 
farewell party, a time to look back merely on a common experience at high-school, some of the girls want to take a group picture. But the photo never gets taken and the laughs fade away. The play ends on a new chain of little girls with their arms linked, ready to start over and do it better. From the expression of cohesion to that of expulsion of what seems abnormal, laughter is a dramatic gesture on stage that not only fosters the process of identification between the characters but is also meant to reach the audience.

\section{Laughter in the audience: How do distancing and empathy operate together?}

The performance of laughter on stage is supposed to have a performative effect - it extends from the actors on stage to the audience. The youth effect allows the identification of the teenage audience with the characters and the action on stage. By watching people laugh on stage, the audience internalize the conflict about inclusion and exclusion - they have to face the same dilemmas as the characters. Through laughter, or its absence, as it is a collective experience, the conflict is transferred into the audience's body. But laughter is never cathartic in a Placey play. Whether the audience are affected by contagious laughter or not, laughing still raises the question of identification: do they share the same codes as the character? Do they laugh with the laugher? Or do they feel compassion for the laughed-at? Laughter therefore also has a dramaturgical role, which is paradoxically to put at a distance what is happening on stage so that the audience can cast a reflexive look on the conflicts they are witnessing - it sharpens their critical sense. The emotional response really is an ethical choice. What Placey calls the "'heightened' realistic naturalism" of his plays can be seen as his own understanding of the epic tradition of constant solicitation of the spectator that comes from Brecht - laughing is a tool to develop critical analysis by inducing an alienation effect which it generates and by encouraging the audience to respond rationally rather than emotionally.

Such distance is introduced by the use of metacomments like "Secondary school is a cliché. Teenagers are a cliché" in Banana Boys, which points at the hyperrealism of the play, the construed nature of which is always denounced by the intrusion of the chorus of Banana Girls. The audience are therefore encouraged to question the clichés that are unravelling in front of them.

Besides, Placey, even though very attentive to youth speech, nonetheless uses a "heightened, poetic form of language" (Placey 2015). For instance, in Banana Boys, Riley delivers a monologue that is close to spoken word poetry to show that he is very wellversed in sex matters and to make the sex-ed student-teacher he is talking to uncomfortable and intimidated by his knowledge of sexuality (Placey 49). His speech is rife with slang, so much so that he sounds "ridiculous" (Placey 2017), nonsensical in an Edward Lear kind of way i.e. the words connect through alliteration and assonance more than through meaning. It is interesting to note that when Rupert Rowbothan, Head of Engagement at Nuffield Theatre, read this excerpt in the "Writers in Conversation" series at Southampton University, the audience laughed because of the distance between the over-articulate, costume-wearing, middle-aged man and the goofy content of this nevertheless poetic text. Another poetic device that jeopardizes the identification by pinpointing at the constructed nature of the play is that of 
anaphora. For instance, in Girls Like That, the girls, one at a time, rejoice in the collective memories they share, introducing each memory by "Girls who remember when..." (Placey 179-180). But the more the list goes, the more sad and gruesome memories become. In the video recording of the Webb Schools Fall Play (2014), an American high-school production of the play, the audience is heard laughing but the quality of the laughs changes to give way to an uncomfortable laugh. Parallel to this, on stage, at the end of the scene, the girls giggle and smirk, meaning that they put on fake smiles to keep up with the image of a united group while the audience, who sense the unity is breaking down, is left wondering whether this was funny at all in the first place. $^{3}$ Of course, the audience's laughter in this case is also due to affect since the audience are the actors' schoolmates and families, who usually are happy to see a loved one on stage. But in a dialectic movement, the audience is also made uncomfortable: Can my friend or my child actually say something like that and laugh about it? Should I laugh too or give them a good tell off? How could I get carried away by such meanness?

In the end, laughter becomes corrective because the audience laugh at the object of laughter until they start laughing at the one who is passing on a judgment. Laughter therefore sets the world straight and such scenes create a community of laughter, which has nothing to do with the community of judgment that is evolving on stage. This is reminiscent of the Nietzschean philosophical tradition that privileges "laughter" and other gay forms of "sovereign communication" in the formation of "community".

The question Placey's plays raise therefore is: Should teenagers learn to conform to group expectations, accept social rules, or should they find their own way to be in the world? And should I, as a member of the audience, side with the laughers or with the laughed-at? The answer is not straightforward, because it is hard to blame someone who commits to the group knowing it is so hard to maintain the illusion of a united group. Empathy and distancing thus go hand in hand to make the audience reflect on their own ethics.

\section{Conclusion}

Such a teen kind of laughter raises the issue of the minor status of youth drama. There is undoubtedly a youth effect in the "laughing-out-loud" moments of Placey's plays. Indeed it can be argued that laughter changes the aesthetic of the plays by turning them from "plays for teenagers" into "teenage plays". Indeed, laughter is also part of "becoming-teen", the equivalent of Deleuze and Guattari's "becoming-child" (Deleuze and Guattari 313). Though written by an adult, the text is not adult-centred but open to a change of perspective. Becoming-teen allows the playwright to deconstruct normative identity, which is described by Deleuze and Guattari as "the average adultwhite-heterosexual-European-male speaking a standard language" (Deleuze and Guattari 116). The audience are included in the process of defamiliarization introduced by the hyperrealistic youth language and culture and have to navigate between identification and distancing. The audience are constantly negotiating their position as spectators of the play: they are not passive but active in the process of construction of meaning, and every time they laugh - or don't laugh - they make an ethical and aesthetic choice. 


\section{BIBLIOGRAPHY}

Barthes, Roland. "L'effet de réel." Communications 11 (1968): 84-89.

Bergson, Henri. Le Rire: essai sur la signification du comique (1900). Paris: Gallimard, 2013.

Bernanoce, Marie and Sandrine Le Pors. Poétiques du théâtre jeunesse. Arras: Artois Presses Université, 2013.

“Cappies Reviews: Girls Like That”. Edmonton Journal. March 22, 2017. https://www.cbc.ca/ news/entertainment/teen-theatre-consent-harassment-1.4643672. Last accessed: 30.09.18.

Deleuze, Gilles and Felix Guattari. A Thousand Plateaus: Capitalism and Schizophrenia (1980). Transl. Brian Massumi. Minneapolis: University of Minnesota Press, 1987.

Drugeon, Marianne et Florence March. « Atelier de traduction de théâtre : un projet collaboratif de l'Université Paul-Valéry (Montpellier) ». Miranda 16 (2018). http://journals.openedition.org/ miranda/11680. Last accessed: 30.09.18.

Galland, Olivier. Sociologie de la jeunesse. Paris : Armand Colin, 2011.

Girard, René. Violence et Sacré (1972). Paris: Fayard, 2011.

Kamieniak, Jean-Pierre. “Les Humours adolescentes.” Topiques 92 (2005): 79-90.

Maguire, Tom and Karian Schuitema. Theatre for Young Audiences: A Critical Handbook. Institute of Education Press, 2012.

Pasquier, Dominique. Cultures lycéennes. La Tyrannie de la majorité. Paris: Editions Autrement, 2005.

Pfister, Manfred, ed. A History of English Laughter - Laughter from Beowulf to Beckett and Beyond. Amsterdam; New York: Rodopi, 2002.

Placey, Evan. Girls Like That and Other Plays for Teenagers. London: Nick Hern Books, 2016.

--- Conference at Lille University, "From text(ing) to staging," 13.02.2015. https://rpn.univlille3.fr/public/aulias/evanPlacey/co/EvanPlacey-10.html Last accessed: 30.09.18.

--- "Word from the Playwright," Synergy Theatre Project Resource Pack http://

www.synergytheatreproject.co.uk/wp-content/uploads/2014/03/HJ-Teacher-Resource-Pack.pdf. Last accessed: 30.09 .18 .

Proyer René T., Lukas E. Meier, Tracey Platt, Willibald Ruch. "Dealing with Laughter and Ridicule in Adolescence: Relation with Bullying and Emotional Responses." Social Psychology of Education 16:3 (2013): 399-420.

Spencer, Herbert. "On the Physiology of Laughter" (1860). Essays 2 (1901): 225.

Webb Schools Fall Play. https://www.youtube.com/watch?v=hCokomk8I9E. Last accessed: 30.09.18.

Wong, Jessica. “Teaching teens about \#MeToo Through Theatre”. CBC News. May 07, 2018. https://www.cbc.ca/news/entertainment/teen-theatre-consent-harassment-1.4643672. Last accessed: 30.09.18. 


\section{NOTES}

1. In spite of the fact that Placey is recognized as an important writer for teenagers and actively participates in conferences all over the world (Lille in 2015, Montpellier in 2017 for France), little has been written on his plays, apart from reviews. The same can be said about teenage drama, a branch of children theatre.

2. "un engagement dépassant le seul théâtre destiné aux jeunes et interrogeant à la fois le monde et le théâtre, la jeunesse et les adultes soucieux de regarder le monde tel qu'il est depuis l'enfance. » (BERNANOCE and LE PORS back cover, my translation)

3. The same conclusion can be drawn from my experience of putting up extracts of Girls Like That with my Performing Arts Students during a one-day conference Evan Placey attended in 2015 despite the language barrier, the performance elicited quite a few smiles that were not pity smiles but smiles of recognition that something funny was happening. These smiles faded into expressions of disgust.

\section{ABSTRACTS}

Evan Placey, an Anglo-Canadian playwright, writes for teenagers. In spite (or because) of the serious and painful themes he tackles in his plays (coming out in Banana Boys, social determinism in Holloway Jones, bullying in Girls Like That, gender reassignment in Pronoun), the characters laugh, and so do the audience. In Placey's plays, humour - be it linguistic, cultural, contextual, steeped in the news or in the playwright's field experience with young people - belongs to a specific youth culture; but laughter, more than humour itself, gives the play a youth effect. Besides, whether on stage or among the audience, laughter is no solitary experience; it is a collective one and it is contagious. It is also a defence mechanism against all those things that cannot be understood or controlled. And since the best defence is a good offence, laughter can unite by excluding everything that is marginal, which hints at its tragic dimension. Laughter, in Placey's work, therefore serves to create a continuous tension between distancing and empathy.

Evan Placey, dramaturge anglo-canadien, écrit pour les adolescents. Malgré (ou à cause) des thèmes sérieux et douloureux abordés dans ses pièces (le coming out dans Banana Boys, le déterminisme social dans Holloway Jones, le harcèlement scolaire dans Girls Like That, la réattribution sexuelle dans Pronoun), les personnages rient, et le spectateur aussi. Linguistique, culturel et contextuel, nourri de l'actualité et de l'expérience de terrain du dramaturge auprès de jeunes gens, l'humour est un humour de jeunes, mais c'est le rire qui donne un effet de jeune. Par ailleurs, sur scène comme dans la salle, le rire n'est pas une expérience solitaire mais collective : le rire est contagieux. C'est aussi un mécanisme de défense face à ce qui échappe à la compréhension, au contrôle. C'est encore une stratégie d'attaque : le rire unit en excluant celui qui est maintenu en marge du groupe et a donc partie liée avec le tragique. Le rire, chez Evan Placey, sert donc à créer une tension constante entre distanciation et empathie. 
INDEX

Mots-clés: Evan Placey, théâtre de jeunesse, rire, distanciation et empathie, effet de jeune

Keywords: Evan Placey, youth theatre, laughter, distancing and empathy, youth effect

\section{AUTHOR}

\section{CLAIRE HÉLIE}

Maître de conférences

Université de Lille

claire.helie@univ-lille.fr 